\title{
Effect of Salicylic Acid on Growth and Bulb Yield of Onion (Allium Cepa L.)
}

\author{
M. Pradhan ${ }^{1 *}$, P. Tripathy' ${ }^{2}$, P. Mandal ${ }^{3}$, B. B. Sahoo ${ }^{4}$, R. Pradhan ${ }^{5}$, S. P. Mishra ${ }^{6}$ and H. N. Mishra \\ ${ }^{1,2,5 \& 7}$ Dept. of Vegetable Science, OUAT, Bhubaneswar, Odisha (751 003), India \\ ${ }^{3}$ AINRP on Onion and Garlic, OUAT, Sambalpur, Odisha (768 025), India \\ ${ }^{4}$ RRTTS (OUAT), Semiliguda, Koraput, Odisha (763 002), India \\ ${ }^{6} \mathrm{KVK}$ (OUAT), Jagatsingpur, Odisha (754 160), India
}

\section{Article History}

Manuscript No. AR1429

Received in $8^{\text {th }}$ August, 2015

Received in revised form $26^{\text {th }}$ June, 2016

Accepted in final form $25^{\text {th }}$ July, 2016

\section{Correspondence to}

*E-mail: m2pradhan@gmail.com

\section{Keywords}

Onion, salicylic acid, vegetative growth, bulb yield

\begin{abstract}
A field experiment was conducted under All India Network Research Project on Onion and Garlic operating at College of Horticulture (OUAT), Sambalpur, Odisha India during winter season of 2013-14 to study the efficacy of exogenous application of salicylic acid (SA) on growth and yield in onion var. Agrifound Light Red. The experiment was laid out in RBD with four replication having six treatments of different sprays of SA including control. The results revealed exogenous application of SA significantly increased the better vegetative growth in terms of plant height $(68.18$ to $71.08 \mathrm{~cm}$ ), collar thickness (16.90 to $18.51 \mathrm{~mm}$ ) with higher level of chlorophyll content of leaves (31.53 to $33.01 \mathrm{SPAD})$ than untreated control $(61.71 \mathrm{~cm}, 15.29$ $\mathrm{mm}, 26.77$ SPAD, respectively). Further among different times of SA application, foliar spray of SA at 30 days after sowing (DAS) in nursery, 30 and 45 or 60 days after transplanting (DAT) recorded significantly maximum vegetative parameters than rest of spray schedule. Similar trend was also recorded for bulb yield and yield attributing parameters. Spraying of SA at 3 times had better efficacy than 2 times of spraying in terms of bulb diameter (polar: 65.60 to $67.94 \mathrm{~mm}$ and equitorial: 49.10 to $49.80 \mathrm{~mm}$ ), bulb weight (59.50 to $69.25 \mathrm{~g}$ ), marketable bulb yield (180.91 to 183.10 $\mathrm{qha}^{-1}$ ) and total bulb yield (266.99 to $290.91 \mathrm{q} \mathrm{ha}^{-1}$ ). Hence, it may be concluded that application of SA at 30 DAS, 30 DAT and/ or 45 or 60 DAT not only increased the vegetative growth but also bulb yield in onion variety ALR.
\end{abstract}

\section{Introduction}

Onion (Allium cepa L.) is one of the commercial vegetable and spice crops of India. India ranks $2^{\text {nd }}$ position both in area (9.59 lakh ha) and production (163.09 lakh ton) with an average productivity of $17.01 \mathrm{t} \mathrm{ha}^{-1}$ in the world (FAOSTAT, 2013). In India, it is treated as most important export oriented vegetable, exporting to the tune of 1238102.6 tones of Rupees 230054.14 lakhs during 2014-2015 (Saxena et al., 2016). In India, onion is predominantly cultivated during winter (60\%) followed by $20 \%$ each in kharif and late kharif season. The lower productivity of Indian onion is primarily due to cultivation of low yield potential varieties having susceptibility to both biotic (pests and diseases) as well as abiotic factors (i.e. moisture stress, high temperature, imbalance nutrition etc.). Commercial crops like onion are exposed to a wide array of damaging agents, including biotic (viroids, viruses, bacteria, fungi, insects) and abiotic (drought, salinity, heat, cold, soil toxicity) environmental aggressions. To cope with these continuous challenges under field conditions, plants have evolved broad and efficient mechanisms to obtain an adequate defense. One prominent defensive response of plants against pathogen attack is the synthesis of a remarkably vast array of low molecular weight compounds with disparate functions in plant-pathogen interactions (Dixon, 2001). Salicylic Acid (SA) recently included in the class of phytohormones for proper plant growth development and induction of tolerance to both biotic as well as abiotic stresses. In general, SA is an important defensive signal in plants that is essential for elicitor triggered immunity and the establishment of Systemic Acquired Resistance (SAR) (Carr et al., 2010). Thus, SA is an endogenous growth regulator with phenolic nature, which participates in regulation of several physiological processes in crop plants such as stomata closure, ion uptake, inhibition of ethylene biosynthesis and transpiration (Khan et al., 2003 and Shakirova et al., 2003). In addition to its role towards biotic stresses, SA is also believed to play a key role in plant responses to many abiotic stresses such as ozone ( Kochroo et 
al., 2000), heat stress (Dat et al., 1998), chilling stress (Janda et al., 1999; Metwally et al., 2003), drought stress (Senaratna et al., 2000; Singh and Usha, 2003) etc.

As a whole, though these studies clearly suggests the involvement of SA in realization of different antistress functions in crop plants, but not much information was available on the efficacy of SA in one of the most important export oriented commercial vegetable crop of India, Onion. Keeping this in view, a field experiment was conducted under All India Network Research Project on Onion and Garlic operating at College of Horticulture (OUAT), Sambalpur, Odisha, India during winter seasons of 2013-14 to study about the effect of salicylic acid on growth and bulb yield of onion.

\section{Materials and Methods}

A field experiment was conducted during rabi season of 2013-14 under AINRP on Onion and Garlic at College of Horticulture, Chiplima, Sambalpur, Orissa University of Agriculture and Technology (OUAT), Odisha, India. Soil of the experiment area was sandy loam having $\mathrm{pH}$ of 5.4; available NPK 198.7:31.6:115.0 $\mathrm{kg} \mathrm{ha}^{-1}$. The field trial was laid out by adopting RBD replicated four with six treatments. The six treatment schedule consisting of foliar application of SA @ $250 \mathrm{mg} \mathrm{l}^{-1}$ at 30 days after sowing (DAS) followed by second spray either at 30 days after transplanting (DAT) $\left(\mathrm{T}_{1}\right), 45 \mathrm{DAT}$ $\left(\mathrm{T}_{2}\right), 60$ DAT $\left(\mathrm{T}_{3}\right)$ or foliar application of SA @ $250 \mathrm{mg} \mathrm{L}^{-1}$ at 30 DAS followed by 30 and 45 DAT $\left(\mathrm{T}_{4}\right), 30$ and 60 DAT $\left(\mathrm{T}_{5}\right)$ along with an untreated control, without $\mathrm{SA}\left(\mathrm{T}_{6}\right)$. Onion seeds variety Agrifound Light Red (ALR) obtained from the NHRDF, Nasik were sown in the nursery beds on 4.10.2013 at a distance of $5 \mathrm{~cm}$ and at a depth of $2 \mathrm{~cm}$. The seedlings are sprayed with SA@250 mg L-1 of water at 30 DAS except the control treatment, as per the treatment schedule. About 55 days old seedling of $10-15 \mathrm{~cm}$, height were transplanted in the field on 29.11.2013 at a spacing of $15 \times 10 \mathrm{~cm}^{2}$. All the recommended package of practices was adapted uniformly to all the treatments except the exogenous application of SA. The data recorded on various parameters were subjected to statistical analysis as per the procedure suggested by Sukhatme and Amble (1995).

\section{Results and Discussion}

\subsection{Effect of SA on vegetative growth parameter}

A perusal of Table 1 indicated signification variations in plant height due to application of different times of spraying of Salicylic Acid (SA) @ $250 \mathrm{mg} \mathrm{L}^{-1}$ observed at 75, 90 and 105 days after transplanting (DAT). During the three stages of crop growth, significantly maximum plant height was recorded in $\mathrm{T}_{4}$, closely followed by $\mathrm{T}_{2}, \mathrm{~T}_{3}$ and $\mathrm{T}_{5}$, where statistical parity was observed. Similar trend was also observed in pooled results over three stages of crop growth. Regarding the collar thickness of onion plants, the results revealed significantly maximum collar thickness of $20.36 \mathrm{~mm}, 20.65 \mathrm{~mm}$ and $14.53 \mathrm{~mm}$ at 75 , 90 and 105 DAT was recorded in $\mathrm{T}_{5}$, closely followed by $\mathrm{T}_{1}$, $\mathrm{T}_{3}$ and $\mathrm{T}_{4}$, where statistical parity was observed. Similar trend was also observed in pooled results over three stages of crop growth in onion.

Exogenous application of SA had a significant effect on chlorophyll content of leaves at three different stages of crop growth on 75, 90 and 105 DAT (Table 1). The results revealed significantly maximum chlorophyll content was recorded in $\mathrm{T}_{5}$, followed by $\mathrm{T}_{3}$ and $\mathrm{T}_{4}$, where statistical parity was observed at three stages of crop growth. The data also showed significant influence on chlorophyll content of leaves in treatment, $\mathrm{T}_{5}$ (33.01 SPAD) and $\mathrm{T}_{4}$ (32.29 SPAD) than rest of the treatments pooled over the three stages of crop growth. Significantly lowest chlorophyll content of 26.77 SPAD was recorded in $\mathrm{T}_{6}$. Thus, the results of present study clearly demonstrated that SA at more times of spraying had significant effect than less

Table 1: Effect of SA on plant height $(\mathrm{cm})$, collar thickness $(\mathrm{mm})$ and chlorophyll content of leaves in onion var. ALR

\begin{tabular}{|c|c|c|c|c|c|c|c|c|c|c|c|c|}
\hline \multirow[t]{3}{*}{ Treatment } & \multicolumn{4}{|c|}{ Plant height $(\mathrm{cm})$ at } & \multicolumn{4}{|c|}{ Collar thickness $(\mathrm{mm})$ at } & \multicolumn{4}{|c|}{ Chlorophyll (SPAD) content of leaves at } \\
\hline & 75 & 90 & 105 & Mean & 75 & 90 & 105 & Mean & 75 & 90 & 105 & Mean \\
\hline & DAT & DAT & DAT & & DAT & DAT & DAT & & DAT & DAT & DAT & \\
\hline $\mathrm{T}_{1}$ & 59.75 & 72.00 & 63.38 & 65.04 & 17.77 & 19.68 & 13.24 & 16.90 & 31.41 & 35.75 & 21.10 & 29.42 \\
\hline $\mathrm{T}_{2}$ & 63.53 & 76.50 & 64.50 & 68.18 & 17.29 & 18.42 & 12.83 & 16.18 & 32.08 & 36.34 & 22.90 & 30.44 \\
\hline $\mathrm{T}_{3}$ & 66.13 & 76.75 & 65.63 & 69.50 & 18.18 & 19.47 & 13.59 & 17.08 & 33.00 & 36.63 & 24.95 & 31.53 \\
\hline $\mathrm{T}_{4}$ & 66.50 & 80.63 & 66.13 & 71.08 & 18.47 & 20.52 & 14.31 & 17.77 & 33.57 & 36.57 & 26.72 & 32.29 \\
\hline $\mathrm{T}_{5}$ & 64.13 & 78.13 & 67.00 & 69.75 & 20.36 & 20.65 & 14.53 & 18.51 & 33.97 & 37.50 & 27.56 & 33.01 \\
\hline $\mathrm{T}_{6}$ & 55.63 & 69.63 & 59.88 & 61.71 & 16.38 & 17.59 & 11.89 & 15.29 & 30.17 & 30.51 & 19.64 & 26.77 \\
\hline Mean & 62.61 & 75.60 & 64.42 & 67.54 & 18.07 & 19.39 & 13.40 & 16.95 & 32.37 & 35.55 & 23.81 & 30.57 \\
\hline $\mathrm{SEm} \pm$ & 2.29 & 3.32 & 2.05 & 1.77 & 1.11 & 0.82 & 0.79 & 0.71 & 1.01 & 0.48 & 0.48 & 0.48 \\
\hline $\mathrm{CD}(p=0.05)$ & 4.89 & 7.07 & 4.37 & 3.78 & 2.36 & 1.75 & 1.69 & 1.51 & 2.16 & 1.03 & 1.02 & 1.02 \\
\hline
\end{tabular}

DAT: Days After Transplanting; SPAD: SPAD-Values are commonly used to express the relative leaf chlorophyll content 
number of spraying. The present study also clearly indicated the beneficial impact of SA on crop growth, which might be due to the involvement SA in regulation of several physiological processes in plants such as stomata closure, ion uptake, inhibition of biosynthesis and transpiration (Khan et al., 2003 and Shakirova et al., 2003). SA had also prolific effects on both morphology and physiology of plants (Piperpoint, 1996 and Poncheva et al., 1996). Exogenous application of SA had effect on increased photosynthetic activity which enhances the number of leaves plant ${ }^{-1}$ and chlorophyll content, there by plant height (Gharib, 2006). Similar reports on beneficial effects of SA on vegetative growth in form of plant height, number of leaves plant ${ }^{-1}$, chlorophyll content of leaves have also been reported in several crops, such as El- Tayeb (2005) in chilli; Amin et al. (2007) in onion; Gawade and Sirohi (2011) in brinjal and Khandaner et al. (2011) in red amaranthus etc.

\subsection{Effect of salicylic acid on bulb yield and yield attributing parameters}

The results on yield attributing parameters of onion var. ALR revealed significant variations in onion bulb diameter (polar and equatorial) and average bulb weight due to application of different times of spraying of SA (Table 2). Significantly maximum polar diameter of $67.94 \mathrm{~mm}$ was recorded in $\mathrm{T}_{5}$ than rest of the treatments, except $\mathrm{T}_{3}$ and $\mathrm{T}_{4}$, which were statistically at par. On the other hand, significantly maximum diameter of $49.80 \mathrm{~mm}$ was recorded in $\mathrm{T}_{3}$ than control, $\mathrm{T}_{6}(45.82 \mathrm{~mm})$. However, statistical parity was recorded in all the treatments except $T_{1}$ for equatorial diameter of bulbs. The results also indicated that both the diameter (polar and equitorial) was significantly reduced in control plot, without application of SA. This might be due to better photosynthetic efficacy with SA application and increased chlorophyll content of leaves (Amin et al., 2007). The better efficacy of SA increasing the

Table 2: Effect of SA on bulb diameter (mm), bulb weight (g) marketable and total bulb yield of onion

\begin{tabular}{lccccc}
\hline $\begin{array}{l}\text { Treat- } \\
\text { ment }\end{array}$ & $\begin{array}{c}\text { Polar } \\
\text { diam- } \\
\text { eter } \\
(\mathrm{mm})\end{array}$ & $\begin{array}{c}\text { Equato- } \\
\text { rial di- } \\
\text { ameter } \\
(\mathrm{mm})\end{array}$ & $\begin{array}{c}\text { Average } \\
\text { bulb } \\
\text { weight } \\
(\mathrm{g})\end{array}$ & $\begin{array}{c}\text { Market- } \\
\text { able bulb } \\
\text { yield } \\
\left(\mathrm{q} \mathrm{ha}^{-1}\right)\end{array}$ & $\begin{array}{c}\text { Total } \\
\text { bulb } \\
\text { yield } \\
\left.(\mathrm{q} \mathrm{ha})^{-1}\right)\end{array}$ \\
\hline $\mathrm{T}_{1}$ & 62.70 & 48.54 & 55.75 & 106.81 & 214.74 \\
$\mathrm{~T}_{2}$ & 62.72 & 48.78 & 57.00 & 133.29 & 235.23 \\
$\mathrm{~T}_{3}$ & 65.60 & 49.80 & 59.50 & 151.08 & 266.99 \\
$\mathrm{~T}_{4}$ & 66.34 & 49.72 & 63.75 & 183.10 & 277.19 \\
$\mathrm{~T}_{5}$ & 67.94 & 49.10 & 69.25 & 180.91 & 290.91 \\
$\mathrm{~T}_{6}$ & 61.51 & 45.82 & 54.50 & 81.50 & 185.78 \\
$\mathrm{Mean}$ & 64.47 & 48.63 & 59.96 & 139.45 & 245.14 \\
$\mathrm{SEm} \pm$ & 1.77 & 1.21 & 4.61 & 12.23 & 13.55 \\
$\mathrm{CD}$ & 3.78 & 2.57 & 9.83 & 26.06 & 28.88 \\
$(p=0.05)$ & & & & & \\
\hline
\end{tabular}

effective photosynthetic area in terms of plant height, number of leaves plant $t^{-1}$ and chlorophyll content significantly enhance the assimilation of photosynthates in the bulb. Results higher values of polar and equitorial diameter in onion bulbs were also reported by Amin et al. (2007) and that of garlic by Bideshki and Arvin (2010).

Significantly heaviest bulb of $69.25 \mathrm{~g}$ was recorded in the treatment $\mathrm{T}_{5}$ than rest of the treatments except $\mathrm{T}_{3}(59.50 \mathrm{~g})$ and $T_{4}(63.75 \mathrm{~g})$ which were statistical at par. Significantly minimum bulb weight of $54.50 \mathrm{~g}$ was recorded in control plots, $\mathrm{T}_{6}$. The increased bulb weight in the present study by application of SA might be due to the better utilization of photosynthates and increased allocation of photosynthates towards the economic parts, the bulb in onion. Several studies indicated that SA may have a dramatic effect on sugar metabolism in plants. Sugar-the form of simple carbohydrates are well known for its role in plant metabolism in all living cells (Hirabayashi, 1996). In general, both glucose and fructose are the primary sucrose of carbon and energy for plant cells. In oxygenic photosynthesis and is a transport molecule in plant growth development and storage (Couee et al., 2006). Similar report on better efficacy of SA over control was also reported in onion by Amin et al. (2007), garlic by Bideshki and Arvin (2010) and green pea by Hak et al. (2012).

The results presented on total bulb yield and marketable bulb yield of onion var. ALR revealed significant variations among different treatments due to exogenous application of SA (Table 2). The results revealed significantly highest total bulb yield of $290.91 \mathrm{q} \mathrm{ha}^{-1}$ in $\mathrm{T}_{5}$ than rest of the treatments. However, statistically parity were observed with $\mathrm{T}_{3}\left(266.99 \mathrm{q} \mathrm{ha}^{-1}\right)$ and $\mathrm{T}_{4}$ (277.19 $\mathrm{q} \mathrm{ha}^{-1}$ ) Significantly highest marketable bulb yield of $183.10 \mathrm{q} \mathrm{ha}^{-1}$ was recorded in $\mathrm{T}_{4}$, closely followed by $\mathrm{T}_{5}(180.91$ $\mathrm{q} \mathrm{ha}^{-1}$ ) than rest of the treatments. However, both $\mathrm{T}_{4}$ and $\mathrm{T}_{5}$ were statistically at par. Similar report of higher bulb yield in onion with application of SA than the control was also reported by Amin et al. (2007). The higher marketable bulb yield might be due to enhanced assimilation of nutrient uptake, nutrient reduction and photosynthesis improved flow assimilates and increased cell integrity which in term reflected on the increased bulb yield of the onion plants. Better efficacy of SA in garlic was also reported by Bideshki and Arvin (2010), which might be due to accumulation of more chlorophyll content in SA treated plants, responsible for the improved fresh and dry matter accumulation there by final bulb yield.

\section{Conclusion}

Foliar spray of Salicylic Acid (SA) is essential for onion crop. Foliar spray of SA@ $250 \mathrm{mg} \mathrm{L}^{-1}$ at 30 days after sowing during nursery seedling stage, subsequently second spray at 30 days after transplanting and third spray at either 45 or 60 days after 
transplanting during crop growth stage not only increase the vegetative growth but also the bulb yield in onion var. ALR.

\section{Acknowledgement}

We gratefully acknowledge the Orissa University of Agriculture and Technology, Odisha, India for the research facilities provided and to the Director, Directorate of Onion and Garlic Research (ICAR), Rajgurunagar, Pune, India for providing the financial and other facilities to carry out this study under AINRP on Onion and Garlic.

\section{References}

Amin, A.A., Rashad, M., EL-Sh, EL-Abagy, H.M.H., 2007. Physiological effect of indole-3-butyric acid and salicylic acid on growth, yield and chemical constituents of onion plants. Journal of Applied Science Research 3(11), 1554-1563.

Bideshki, A., Arvin, M.J., 2010. Effect of salicylic acid (SA) and drought stress on growth bulb yield and allicin content of garlic in field. Plant Ecophysiology 2, 73-79.

Carr, J.P., Lewsey, M.G., Palukaitis, P., 2010. Signaling in induced resistance. Advances in Virus. Research 76, 57-121.

Couee, I., Sulmon, C., Gouesbet, G., Amrani, A.E., 2006. Involvement of soluble sugars in reactive oxygen species balance and responses to oxidative stress in plants. Journal of Experimental Botany 57(3), 449-459.

Dat, J.F., Foyer, C.H., Scote, I.M., 1998. Changes in Salicylic acid and antioxidants during induced thermo tolerance in mustard seedlings. Plant Physiology 118, 1455-1466.

Dixon, R.A., 2001. Natural product and plant disease resistance. Nature 411, 843-847.

El-Tayeb, M.A., 2005. Response of barley grains to the interactive effect of salinity and salicylic acid. Plant Growth Regulator 45, 215-224.

FAOSTAT. 2013. Food and Agriculture Organization of the United Nations. http://faostat.fao.org/site/567/ DesktopDefault.aspx? Page ID=567\#ancor.

Gawade, B., Sirohi, A., 2011. Induction of Resistance in Eggplant (Solanum melongena) by Salicylic Acid against Root-Knot Nematode, Meloidogyne incognita. Indian Journal of Nematology 41(2), 201-205.

Gharib, F.A., 2006. Effect of salicylic acid on the growth, metabolic activities and oil content of basil and marjoram. International Journal of Agricultural Biology 4, 485-492.

Hak, E.L., Gunes, A., Inal, A., Alpaslan, M., Eraslan, F., Guneri, B.E., Cicek, N., 2012. Salicylic acid induced changes on some physiological parameters symptomatic for oxidative stress and mineral nutrition in green pea (Pisum sativum) grown under salinity. Journal of Plant Physiology 164, 728-736.
Janda, T., Szalai, G., Tari, I., Paldi, E., 1999. Hydroponic treatment with salicylic acid decreases the effects of chilling injury in maize (Zea mays L.) plants. Planta 208, 175-180.

Kachroo, P., Yoshioka, K., Shah, J., Dooner, H.K., Klessig, D.F., 2000. Resistance to turnip crinkle virus in Arabidopsis is regulated by two host genes and is salicylic acid dependent but $N P R 1$,ethylene, and jasmonate independent. Plant Cell 12, 677-690.

Khan, W., Prithiviraj, B., Smith, D.L., 2003. Photosynthetic responses of corn and soybean to foliar application of salicylates. Journal of Plant Physiology 160, 485-492.

Khandaker, L., Masum, A.S.M.G., Shinya, O.B.A., 2011. Foliar application of salicylic acid improved the growth, yield and leaf's bioactive compounds in red amaranthus (Amaranthus tricolor). Vegetable Crop Research Bulletin 74, 77-86.

Leslie, C.A., Romani, R.J., 1986. Salicylic acid a new inhibitor of ethylene biosynthesis. Plant Cell Reports 5(2), 144-146.

Metwally, A., Finkemeirer, I., Georgi, M., Dietz, K.J., 2003. Salictlic acid alleviates the cadmium toxicity in barley seedlings. Plant Physiology 132, 272-282.

Pierpoint, W.S., 1994. Salicylic acid and its derivatives in plants: medicines, metabolites and messenger molecules. Botanical Research 20, 163-235.

Poncheva, T.V., Popova, L.P., Uzunova, A.N., 1996. Effect of salicylic acid on growth and photosynthesis in barley plants. Journal of Plant Physiology 149, 57-63.

Saxena, M., Bhattacharya, S., Malhotra, S.K., 2016. Export of fresh onion. Horticultural Statics at a glance 2015. Horticultural Statics Division, Department of Agriculture, Cooperation \& Family Welfare, Ministry of Agriculture \& Farmers Welfare, Govt. of India. Published in India by Oxford University Press. YMCA Library Building, 1 Jai Singh Road, New Delhi 110001, India, 392.

Seneratna, T., Touchell, D., Bunn, E., Dixon, K., 2000. Aceta salicylic acid (Asprin) and salicylic acid induce multiple stress tolerance in bean and tomato plants. Plant Growth Regulator 30, 157-161.

Shakirova, M.F., Sakhabutdinova, A.R., Bezrukova, M.V., Fathutdinova, R.A., Fathutdinova, D.R., 2003. Change in the hormonal status of wheat seedling induced by salicylic acid and salinity. Plant Science 164(3), 317-322.

Singh, B., Usha, K., 2003. Salicylic acid induced physiological and biochemical changes in wheat seedlings under water stress. Plant Growth Regulator 39, 137-141.

Sukhatme, P.V., Amble, V.N., 1995. Randomized Blocks Designs. In: Statistical Methods for Agricultural Workers, Krishi Anusandhan Bhavan, Pusa, New Delhi, India, 145-156. 